\title{
Prior height, growth, and wood anatomy differently predispose to drought-induced dieback in two Mediterranean oak species
}

\author{
J. Julio Camarero ${ }^{1}$ - Gabriel Sangüesa-Barreda ${ }^{1} \cdot$ Marta Vergarechea $^{1}$
}

Received: 21 July 2015 / Accepted: 10 September 2015 /Published online: 25 September 2015

(C) INRA and Springer-Verlag France 2015

\begin{abstract}
- Key message Coexisting Mediterranean oaks are differently predisposed to heat- and drought-induced dieback as a function of height, prior growth, wood anatomy, and growth responsiveness to temperatures. To forecast postdieback damage, the variability of species and individual traits must be considered.

- Context Forests are susceptible to drought-induced dieback. However, considerable variability in how drought translates into tree damage exists in coexisting species.

- Aims This study aimed to assess if tree size, radial growth, and wood anatomy predisposed trees to drought damage, measured as defoliation and changes in non-structural carbohydrate (NSC) concentrations.

- Methods We measured radial growth, wood anatomy, and post-drought NSC concentrations in highly defoliated and less
\end{abstract}

Handling Editor: Erwin Dreyer

Contributions of co-authors G. Sangüesa-Barreda and J.J. Camarero performed field sampling. M. Vergarechea and J.J. Camarero carried out the anatomical and statistical analyses, respectively. J.J. Camarero led the writing of the paper, and all authors contributed to the discussion.

Electronic supplementary material The online version of this article (doi:10.1007/s13595-015-0523-4) contains supplementary material, which is available to authorized users.

J. Julio Camarero

jjcamarero@ipe.csic.es

Gabriel Sangüesa-Barreda

gsanguesa@ipe.csic.es

Marta Vergarechea

vergarechea.marta@gmail.com

1 Instituto Pirenaico de Ecología, CSIC (IPE-CSIC), Avda. Montañana 1005, Apdo. 202, 50192 Zaragoza, Spain defoliated holm oak (Quercus ilex) and Portuguese oak (Quercus faginea) trees co-occurring in a coppice stand.

- Results Highly defoliated trees showed a lower height than less defoliated individuals. In holm oak, a reduced previous growth and the formation of vessels with smaller lumen areas predisposed to drought damage, which suggests hydraulic deterioration. In Portuguese oak, most defoliated trees grew less in response to elevated growing season temperatures. Sapwood starch and NSC concentrations decrease in defoliated holm oaks.

- Conclusion A height-dependent predisposition modulates the responses to drought-induced dieback in Mediterranean oak coppices. Coexisting oak species presented different predisposing factors to drought-induced dieback related to growth (holm oak) and its sensitivity to temperature (Portuguese oak). To forecast post-dieback damage, we should consider the variability of traits between and within species.

Keywords Drought stress $\cdot$ Holm oak $\cdot$ Mediterranean oak coppice · Portuguese oak · Quercus faginea · Quercus ilex

\section{Introduction}

Globally, most forests are at risk of hydraulic dysfunction when there is a significant soil water deficit (Choat et al. 2012). Drought-induced dieback, usually manifested as foliage loss and growth decline, is a secondary manifestation of the dysfunctions in hydraulic tree systems (Allen et al. 2010). However, considerable variability in the vulnerability to cavitation due to drought stress exists among coexisting species and individuals (Meinzer et al. 2009; Nardini et al. 2013). The varied responses of tree species to drought have been linked to the variability of hydraulic traits such as the water potential at which $50 \%$ of hydraulic conductivity is lost 
(Anderegg 2015). Nevertheless, growth seasonality could also determine how soil moisture deficit is translated into tree damage (Anderegg et al. 2013).

Two physiological mechanisms, which are not mutually exclusive, have been posed to explain forest dieback: hydraulic failure caused by embolism-induced loss of conductance and carbon starvation due to prolonged stomatal closure (McDowell et al. 2008; Sevanto et al. 2014; Sperry and Love 2015). Disentangling the role played by each mechanism is a challenge since droughts not only reduce growth, photosynthesis, and respiration (Hsiao 1973) but also uncouple carbon sinks (growth) from sources (photosynthesis) (Muller et al. 2011). In fact, under moderate water deficits, this uncoupling should lead to increasing concentrations of non-structural carbohydrates (NSC henceforth) in tree tissues (Tardieu et al. 2011). The relative importance of hydraulic failure vs. carbon starvation as drivers of forest dieback also depends on interrelated traits (height, leaf phenology, wood density and anatomy, NSC concentrations, anisohydric vs. isohydric behavior) affecting hydraulic conductance, carbon use, or growth (Hoffmann et al. 2011; Sala et al. 2012).

Forest dieback typically occurs in response to rare, extreme, and unpredictable climatic events such as droughts (Gutschick and BassiriRad 2003), which often precludes monitoring trees before and after the dieback occurs. The opportunistic nature of observational studies can be balanced by following a retrospective approach based on tree ring data. This allows comparing growth and wood anatomy between trees showing different sensitivity to drought and contrasting defoliation degrees. Here, we follow this approach by analyzing the responses of two Mediterranean oak species (holm oak, Portuguese oak) to the exceptionally warm and dry 2012 year which caused widespread forest dieback in eastern Spain (Camarero et al. 2015). The holm oak (Quercus ilex subsp. ballota (Desf.) Samp L.) is an evergreen species which usually retains up to 3-year-old leaves and forms diffuse to semi-ring porous wood (Montserrat-Martí et al. 2009; Campelo et al. 2010). It is dominant in areas of the Iberian Peninsula subjected to continental Mediterranean climate, where it withstands dry and cold conditions (Peguero-Pina et al. 2014). The Portuguese oak (Quercus faginea Lam.) is a winter deciduous species forming ring-porous wood, and it usually coexists with holm oak but dominates mesic sites with basic soils under sub-Mediterranean conditions. However, the Portuguese oak shows an earlier phenological development (most primary and secondary growth occur in spring) than holm oak which is able to grow during summer (MontserratMartí et al. 2009; Albuixech et al. 2012). This is also reflected in the radial growth responses to climate, since tree ring width usually increases in response to wet spring or summer conditions in the case of Portuguese and holm oaks, respectively (Corcuera et al. 2004a, 2004b; Gutiérrez et al. 2011). From an ecophysiological point of view, the holm oak is a drought- tolerant species displaying a tight stomatal control over transpiration, while Mediterranean oak species similar to Portuguese oak show a higher conductance but also experience xylem embolism due to summer drought and freezethaw events in winter (Tognetti et al. 1998).

We take advantage of the extreme 2012 drought (i) to detect predisposing factors to dieback damage related to prior differences in size, growth, and wood anatomy and (ii) to determine if those variables affect post-drought responses. Specifically, we analyze the relationships between climate and previous radial increment and wood anatomy and assess if post-drought defoliation and tissue or organ (leaf, shoot, sapwood) NSC concentrations are related. We expect that the species presenting an earlier growing season in spring (Portuguese oak) will be more negatively affected by warm and dry conditions during that season than the species better adapted to withstand summer drought (holm oak). We also hypothesize that highly defoliated holm oak trees will show accumulated drought damage in terms of growth and wood anatomy because they have to rebuild the whole canopy using carbon stored in the wood. Contrastingly, this is the usual situation for the Portuguese oak whose rapid bud burst and earlywood formation should make it more dependent on stored NSCs synthesized in the previous growing season (Barbaroux and Bréda 2002). Improving our knowledge on factors predisposing trees to dieback would help to better forecast which will be the most vulnerable forests in response to warmer and drier conditions (Bréda et al. 2006), particularly in Mediterranean areas where more extreme droughts are predicted to occur (IPCC 2014).

\section{Material and methods}

\subsection{Study site}

In summer 2013, we selected a mixed oak coppice stand affected by the 2012 drought and situated near Formiche Bajo, eastern Spain ( $40^{\circ} 18^{\prime} 02^{\prime \prime}$ N, $0^{\circ} 52^{\prime} 14^{\prime \prime} \mathrm{W}, 1,120-1,150 \mathrm{~m}$ asl; Supplementary Material, S1). The stand is located on SWoriented steep slope. The holm oak is the dominant tree species (basal area of $13.8 \mathrm{~m}^{2} \mathrm{ha}^{-1}$, mean density of 1,850 stems $\mathrm{ha}^{-1}$ ) followed by the Portuguese oak (basal area of $5.1 \mathrm{~m}^{2} \mathrm{ha}^{-1}$, mean density of $825 \mathrm{stems} \mathrm{ha}^{-1}$ ), and there are also scattered individuals of Juniperus thurifera L. and Juniperus oxycedrus L. The soils are basic and rocky; they mainly belong to the Cambisol type. In the site, trees were coppiced every 20-25 years, but it has not been managed since the 1980s. Holm oak is able to resprout from stump and root, but Portuguese oak only resprouts from the stump (Serrada et al. 1992). We found no evidence of recent fires (scars, charcoal) affecting the study site. 
According to climatic data (period 1960-2013) taken from the Teruel station $\left(40^{\circ} 21^{\prime} 02^{\prime \prime} \mathrm{N}, 1^{\circ} 07^{\prime} 27^{\prime \prime} \mathrm{W}, 900 \mathrm{~m}\right.$ asl.; located at about $25 \mathrm{~km}$ from the study site), the mean annual temperature in the area was $12.1{ }^{\circ} \mathrm{C}$, and the total annual precipitation was $380 \mathrm{~mm}$. The warmest and coldest months were July and January, respectively, with mean maximum and minimum temperatures of 31.1 and $-2.4{ }^{\circ} \mathrm{C}$, respectively. The rainiest and driest months were May and February with 54 and $16 \mathrm{~mm}$ of total precipitation, respectively. Frosts were frequent from November to March (Supplementary Material, Fig. S2). To quantify water deficit, we calculated the monthly water balance as the difference between precipitation and potential evapotranspiration (PET), and monthly PET was estimated using monthly temperature and radiation values following Hargreaves and Samani (1982). In the study area, the mean cumulative annual water balance was $-848 \mathrm{~mm}$. The months with the lowest and highest water balance were July $(-176 \mathrm{~mm})$ and December $(-8 \mathrm{~mm})$, respectively. The minimum water balance is usually observed in July (Supplementary Material, Fig. S2).

To estimate the effect of drought intensity and duration on radial growth, we used the Standardized PrecipitationEvapotranspiration Index (SPEI), which is a multi-scalar drought index integrating the effects of temperature and evapotranspiration on the water balance (Vicente-Serrano et al. 2010). The SPEI varies from negative to positive values corresponding to dry and wet periods, respectively. The SPEI monthly values were calculated for the study site considering the period 1960-2013 and 1-18-month-long scales following Camarero et al. (2015). The SPEI accounts for the negative effect of warmer temperatures on water availability by statistically modeling cumulative water balances. Therefore, different SPEIs are obtained for different time scales representing the cumulative water balance over the previous $n$ months (Vicente-Serrano et al. 2010).

\subsection{Field sampling}

From May to August 2013, we established a 500-m-long transect running parallel to the maximum slope in an area widely affected by the 2012 drought showing defoliation and abundant dead shoots, leaves, and branches (Supplementary Material, Fig. S1). Every $10 \mathrm{~m}$ along the transect, we tagged, measured (diameter at $1.3 \mathrm{~m}$ of all stems, maximum tree height, number of stems), and sampled the holm oak ( $n=50$ trees) or Portuguese oaks ( $n=25$ trees) located closest to that point. All sampled stems were growing from ageing stools.

Defoliation in response to the 2012 drought was regarded as a proxy of tree vigor since changes in crown cover induced by heat and drought stress correspond to modifications in hydraulic conductance and radial growth (Dobbertin 2005; Camarero et al. 2015). For each sampled tree, the proportion of crown cover was estimated to the nearest $5 \%$ (Schomaker et al. 2007). Since estimations of crown cover vary among observers and places, the data were always recorded by the first author, who compared every tree with a reference tree with the maximum amount of foliage at each site. Lowdefoliation trees were considered those with a crown cover of $>50 \%$ and high-defoliation trees those showing cover $\leq 50 \%$ (Camarero et al. 2015). Other classification types of vitality based on different crown cover thresholds (40-60\%) produced similar results as those here presented. Besides, a crown transparency threshold higher than $50 \%$ usually represents weakened trees due to drought-induced defoliation (Eilmann et al. 2013).

\subsection{Tree growth: dendrochronology}

Dendrochronology was used to quantify radial growth of study trees (Fritts 2001). Secondary growth was measured by collecting a stem disk at $0.2 \mathrm{~m}$ from the tallest stem of each individual. We sampled 30 holm oak trees and 16 Portuguese oak trees evenly distributed between the two defoliation classes. Wood samples were sanded until tree rings were clearly visible and then visually cross-dated. Once dated, we measured the tree ring widths to the nearest $0.01 \mathrm{~mm}$ from the pith to the bark along two radii per tree using a binocular scope and a LINTAB measuring device (Rinntech, Heidelberg, Germany). The accuracy of visual cross-dating was checked with the program COFECHA (Holmes 1983). We transformed tree ring width series into annual basal area increment (hereafter abbreviated as BAI) assuming stems were circular and using the following formula:

$\mathrm{BAI}=\pi\left(r_{t}^{2}-r_{t-1}^{2}\right)$

where $r_{t}$ and $r_{t-1}$ are the radii corresponding to rings formed in years $t$ and $t-1$, respectively. We used BAI because this variable is linked to variations in hydraulic conductance in Mediterranean oak trees (Cherubini et al. 2003).

\subsection{Wood anatomy}

To analyze wood anatomy, we selected ten trees per species, five per each defoliation class, showing well-cross-dated series and half of them corresponding to high- or low-defoliation levels. We analyzed the rings formed in the 1990-2013 period which includes several dry (e.g., 1994-1995, 2005) or wet years (1997) potentially affecting the long-term hydraulic performance of trees (Corcuera et al. 2004a). We selected 2013 as the last ring of analyses because this was the last ring formed in several highly defoliated trees (holm oak, three trees; Portuguese oak, two trees). Since we were concerned on drought-related loss in hydraulic conductance, only the earliest formed vessels holding most of the ring conductance were analyzed, i.e., the earlywood vessels in Portuguese oak 
(vessels with ample lumen areas forming the first two to three lines of cells; cf. Alla and Camarero 2012) and vessels located in the first half of the ring in holm oak. A 10-mm-wide strip was cut from each disk encompassing the rings formed in the period 1990-2013. Then, a core microtome was used for surface preparation of each oak sample, after which a combination of black staining and white chalk was utilized for contrast enhancement.

To perform cell anatomical surveys, digital images of each ring were captured using a digital video camera (Leica DFC 290) connected to a light microscope (Olympus BH2) at $\times 12.5-20.5$ magnification and ca. 9, 100 dpi image resolution. Adjacent images were taken for each ring, merged, and then transformed into black and white images. For each selected ring, the considered xylem area and the lumen transversal area of each vessel were measured using the image analysis program Image J (Abramoff et al. 2004). Lastly, we determined how vessels were distributed according to their lumen area and calculated the mean vessel area for the period 1990-2013 considering each defoliation class.

\subsection{Analyses of non-structural carbohydrates}

We assessed how drought-induced defoliation affected NSC concentrations in the stem sapwood, shoots, and leaves (Barbaroux and Bréda 2002; Hoch et al. 2003). We randomly selected ten individuals in each of the two defoliation classes for the two oak species. Sampling was carried out in November 2013 at the end of growing season and in July 2014 when leaves of both oak species were fully developed. In each individual, we sampled the most recently formed shoots and leaves from upper and light-exposed branches. We also sampled the sapwood from the thickest stem of each individual by taking two radial cores at $0.5 \mathrm{~m}$ using a Pressler increment borer. Since bud bursting in 2014 did not occur in most holm oak trees, we assumed that the most recently formed shoots and leaves corresponded to the 2013 cohort. In the Portuguese oak, the leaf and shoot samples of highly defoliated trees usually corresponded to epicormic shoots.

All samples were collected between 10 and $12 \mathrm{~h}$. Samples were transported to the laboratory in a portable cooler. Shoots and leaves were dried in the oven at $60{ }^{\circ} \mathrm{C}$ for $72 \mathrm{~h}$. The outer sapwood portion (ca. $5 \mathrm{~cm}$ ) was visually recognized and separated from each core using a razor blade. Wood samples were subsequently frozen and stored at $-20{ }^{\circ} \mathrm{C}$ until freeze dried. All dried samples were weighted and milled to a fine powder in a ball mill (Retsch Mixer MM301, Leeds, UK). Soluble sugars (SS) were extracted with $80 \%(v / v)$ ethanol and their concentration determined colorimetrically using the phenol-sulfuric method (Buysse and Merckx 1993).
Starch and complex sugars remaining after ethanol extractions were enzymatically reduced. NSCs measured after ethanol extraction are referred to as SS, and carbohydrates measured after enzymatic digestion are referred to as starch. The sum of SS and starch is NSC.

\subsection{Statistical analyses}

Trends in monthly climate variables during the period 1960 2013 were analyzed using the Kendall tau coefficient $(\tau)$. Comparisons of variables between defoliation classes and within each species were assessed using the Mann-Whitney $U$ test. The relationships between tree variables were assessed using the Spearman non-parametric correlation coefficient $\left(r_{\mathrm{s}}\right)$. To compare how BAI changed through time between defoliation classes, we applied linear mixed-effects models after log-transforming BAI values. Finally, the distributions of vessels based on their lumen area were compared between defoliation classes using $\chi^{2}$ tests.

The climate-growth relationships were analyzed by relating BAI individual series to monthly climatic variables (mean maximum and minimum temperatures, precipitation, water balance) separately for each defoliation class and using the Pearson coefficient. These correlations were calculated from previous October to current September, i.e., during the year of tree-ring formation, based on previous analyses of xylem phenology (Corcuera et al. 2004b; Albuixech et al. 2012). The BAI mean series were correlated to the SPEI obtained for 1- to 18-month-long scales (Pasho et al. 2011). To account for the effects of temporal autocorrelation on these correlations, we corrected the probability levels following Mudelsee (2003). All statistical analyses were done using the $\mathrm{R}$ statistical software ( $\mathrm{R}$ Core Team 2015).

\section{Results}

\subsection{Climatic trends and the 2012 drought}

June to August temperatures have significantly risen in the study area $(P<0.005)$, particularly considering maximum or daily temperatures (mean $\tau=0.42$ ). The 2012 drought was characterized by very warm temperatures and dry conditions in May and August (Supplementary Material, Fig. S2). In May 2012, the water balance reached a minimum record of $-163 \mathrm{~mm}$ (Fig. 1).

\subsection{Structure and growth: dendrochronological analyses}

In summer 2014, holm oaks did not produce new shoots since apical buds were dead, whereas highly defoliated 
Fig. 1 Long-term changes in basal area increment (BAI) and water balance. The BAI was calculated for holm $(Q$. ilex $)$ and Portuguese oak ( $Q$. faginea) considering highly defoliated (circles) and less defoliated trees (triangles) after the 2012 drought (values are means $\pm \mathrm{SE}$ ). The right $y$ axis shows the cumulative water balance (bars) from January to June calculated as the difference between precipitation and potential evapotranspiration $(P$ PET; note the reverse scale of this axis)

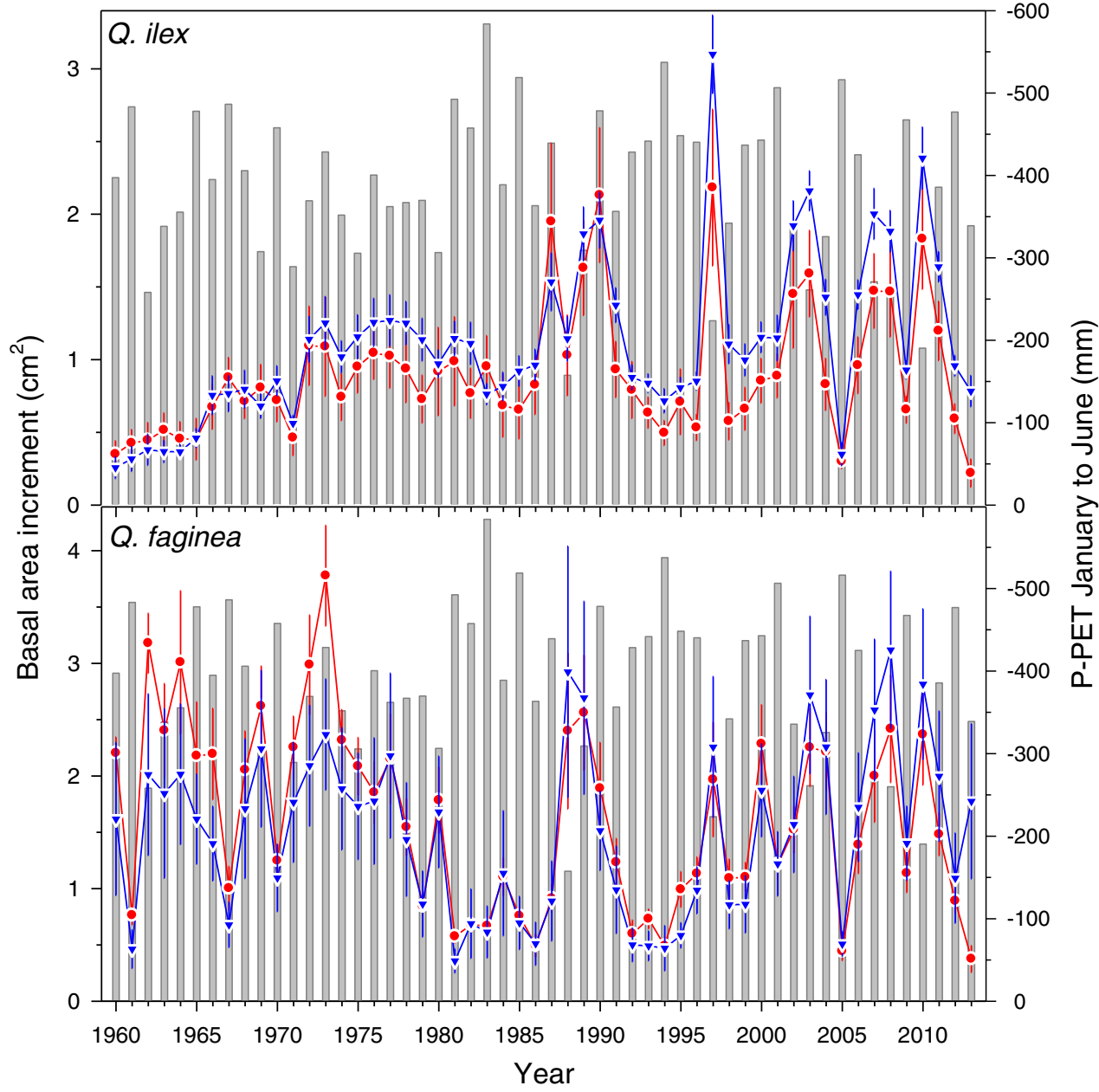

Portuguese oaks only formed epicormic shoots. Highly defoliated trees were smaller than less defoliated individuals (Table 1 ).

Less defoliated holm oak trees grew significantly more during the 1960-2013 period than highly defoliated trees (defoliation effect, $F=47.96, P<0.001$; year $\times$ defoliation effect, $F=8.13, P=0.004$; Fig. 1). These differences were more noticeable during wet years (late 1970s, 1997, 2003, and 2007). In Portuguese oak, highly defoliated trees grew more than non-defoliated trees in the 1960s and early 1970 s, but this trend reversed in the 2000s, this reversal being more obvious after the late 2000s (defoliation effect, $F=1.07, P=0.30$; year $\times$ defoliation effect, $F=9.11, P=$ $0.003)$.

Table 1 Structural features measured in oak trees of different defoliation degrees (high- and low-defoliation trees were defined as those with a crown cover lower or higher than $50 \%$, respectively)

\begin{tabular}{lllll}
\hline Variables & \multicolumn{2}{l}{ Holm oak (Quercus ilex) } & & \multicolumn{2}{l}{ Portuguese oak (Quercus faginea) } \\
\cline { 2 - 3 } & High defoliation & Low defoliation & & High defoliation \\
\hline No. trees & 20 & 30 & 10 & 15 \\
Diameter at $1.3 \mathrm{~m}$, dbh (cm) & $8.7 \pm 0.5$ & $8.7 \pm 0.4$ & $11.3 \pm 0.6$ & $11.7 \pm 1.7$ \\
Height (m) & $3.6 \pm 0.2 \mathrm{a}$ & $4.4 \pm 0.2 \mathrm{~b}$ & $4.2 \pm 0.4 \mathrm{a}$ & $3.1 \pm 0.1 \mathrm{~b}$ \\
No. stems per tree & $9 \pm 1$ & $9 \pm 1$ & $4 \pm 1$ & $3 \pm 1$ \\
Defoliation $(\%)$ & $75 \pm 4 \mathrm{~b}$ & $14 \pm 2 \mathrm{a}$ & $81 \pm 5 \mathrm{~b}$ & $15 \pm 3 \mathrm{a}$ \\
\hline
\end{tabular}

Values are means \pm SE. Different letters indicate significant differences between defoliation classes within each species $(P<0.05$; Mann-Whitney $U$ test $)$ 
Table 2 Growth data and dendrochronological statistics obtained for the residual tree ring width chronologies of the two oak species considering the common period 1970-2013

\begin{tabular}{lllllll}
\hline Species & Tree ring width (mean \pm SD, mm) & \multicolumn{4}{l}{ Residual chronologies } \\
\cline { 3 - 6 } & & AC & MS $_{x}$ & $r_{\mathrm{bt}}$ & & EPS \\
\hline Holm oak (Quercus ilex) & $1.19 \pm 0.75$ & 0.42 & 0.26 & 0.37 & 0.93 \\
Portuguese oak (Quercus faginea) & $0.88 \pm 0.78$ & 0.61 & 0.50 & 0.63 & 0.95 \\
\hline
\end{tabular}

$A C$ first-order autocorrelation, $M S_{x}$ mean sensitivity, $r_{b t}$ correlation between trees, $E P S$ expressed population signal

\subsection{Growth-climate relationships}

The lower average growth rate but higher mean sensitivity $\left(\mathrm{MS}_{x}\right)$ of Portuguese oak as compared with holm oak suggests that the former species was more responsive to water deficit during the growing season than the latter (Table 2). This corresponded to the high BAI-SPEI correlations observed in Portuguese oak which peaked in June at 11 -month-long SPEI time scales $(r=0.69)$, whereas in holm oak, they did it $(r=0.56)$ in July at the 4-month scale (Fig. 2). In addition, BAI of Portuguese oak was enhanced by wet April to June conditions and also by low maximum temperatures in March and late summer (July to August) (Fig. 3). In holm oak, warmer conditions in February and wet and cool conditions in April-May and August enhanced BAI.

Highly defoliated Portuguese oak trees were significantly more responsive to the negative effects of warmer maximum temperatures on BAI in spring and summer (March, July, and August) than less defoliated trees (Fig. 3). A similar pattern was observed in holm oak for the maximum temperatures from May to August, albeit in this species warmer spring-tosummer temperatures were not as significantly associated to decreased BAI as in Portuguese oak. Specifically, in Portuguese, oak defoliation was negatively related to the BAI response to July maximum temperatures $\left(r_{\mathrm{s}}=-0.49, P=\right.$ $0.005, n=16$ ). In the case of holm oak, the higher the defoliation the most negative was the BAI association to June maximum temperatures $\left(r_{\mathrm{s}}=-0.34, P=0.02, n=31\right)$.

\subsection{Wood anatomy}

In holm oak, highly defoliated trees formed more vessels with small transversal areas than less defoliated trees $\left(\chi^{2}=35.4\right.$, $P<0.001)$, whereas this trend reversed in highly defoliated Portuguese oaks which formed wider earlywood vessels $\left(\chi^{2}=57.4, P<0.001\right.$; Fig. 4a). Accordingly, higher average vessel areas were observed in less defoliated holm oak

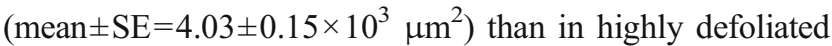
$\left(3.25 \pm 0.10 \times 10^{3}{\mu \mathrm{m}^{2}}^{2}\right.$ ) trees (Mann-Whitney $U=3355, P=$ 0.0004; Fig. 4b). In Portuguese oak, more defoliated trees showed a higher mean earlywood vessel area $(22.5 \pm 0.55 \times$ $\left.10^{3} \mu^{2}\right)$ as compared with less defoliated trees $(20.5 \pm$ $0.46 \times 10^{3} \mu \mathrm{m}^{2}$ ), and the difference was significant (MannWhitney $U=2364, P=0.037$ ).

\subsection{Non-structural carbohydrates}

Highly defoliated holm oak trees presented lowest starch and NSC concentrations than less defoliated trees in summer 2014 (Table 3). Defoliation of holm oak trees was negatively related to their sapwood starch concentration $\left(r_{\mathrm{s}}=-0.84, P<0.001\right)$.
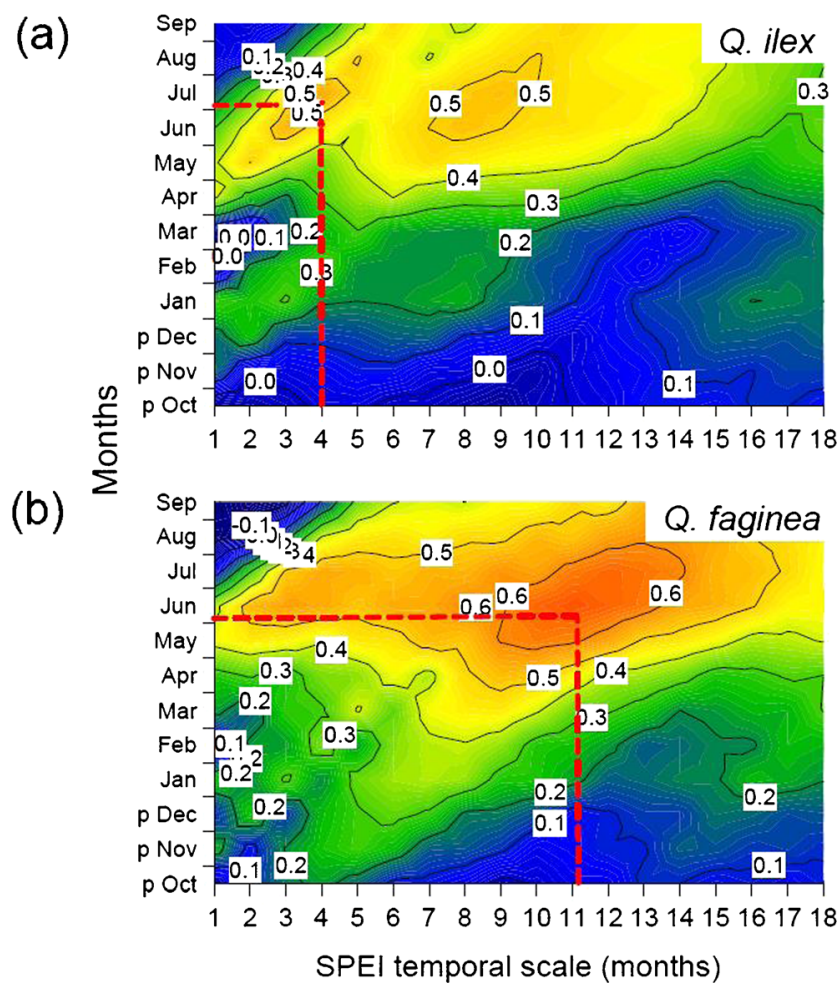

Fig. 2 Basal area increment (BAI) responses of the two oak species to drought. The color scale shows the correlations (Pearson coefficients) calculated between BAI and the SPEI drought index obtained for 1- to 18-month-long scales ( $x$ axis) for holm (a, Q. ilex) and Portuguese oak (b, Q. faginea). The correlations were obtained from the previous October (months prior to the growth year are abbreviated by " $p$ ") to the September of the year of tree-ring formation ( $y$ axis). The dashed lines indicate the SPEI temporal scale ( $x$ axis) and month ( $y$ axis) when the maximum BAISPEI correlation was obtained 
Fig. 3 Individual growth responses to climate calculated by relating basal area increment series to monthly climatic variables for highly defoliated (crown cover $\leq 50 \%$, hatched bars) and less defoliated (crown cover $>50 \%$, empty bars) holm (Q. ilex) and Portuguese oaks (Q. faginea). Values are means \pm SE. Abbreviations of climatic variables: TMax, mean maximum temperatures; TMin, mean minimum temperatures; $P$, precipitation; $P$-PET, water balance or difference between precipitation and potential evapotranspiration (PET). Bars located outside the gray boxes indicate significant correlations $(P<0.05)$. Asterisks indicate significantly different growth responses to climatic variables as a function of the defoliation class (Mann-Whitney $U$ tests, $* P<0.05 ; * * P<0.01$; $* * * P<0.001)$
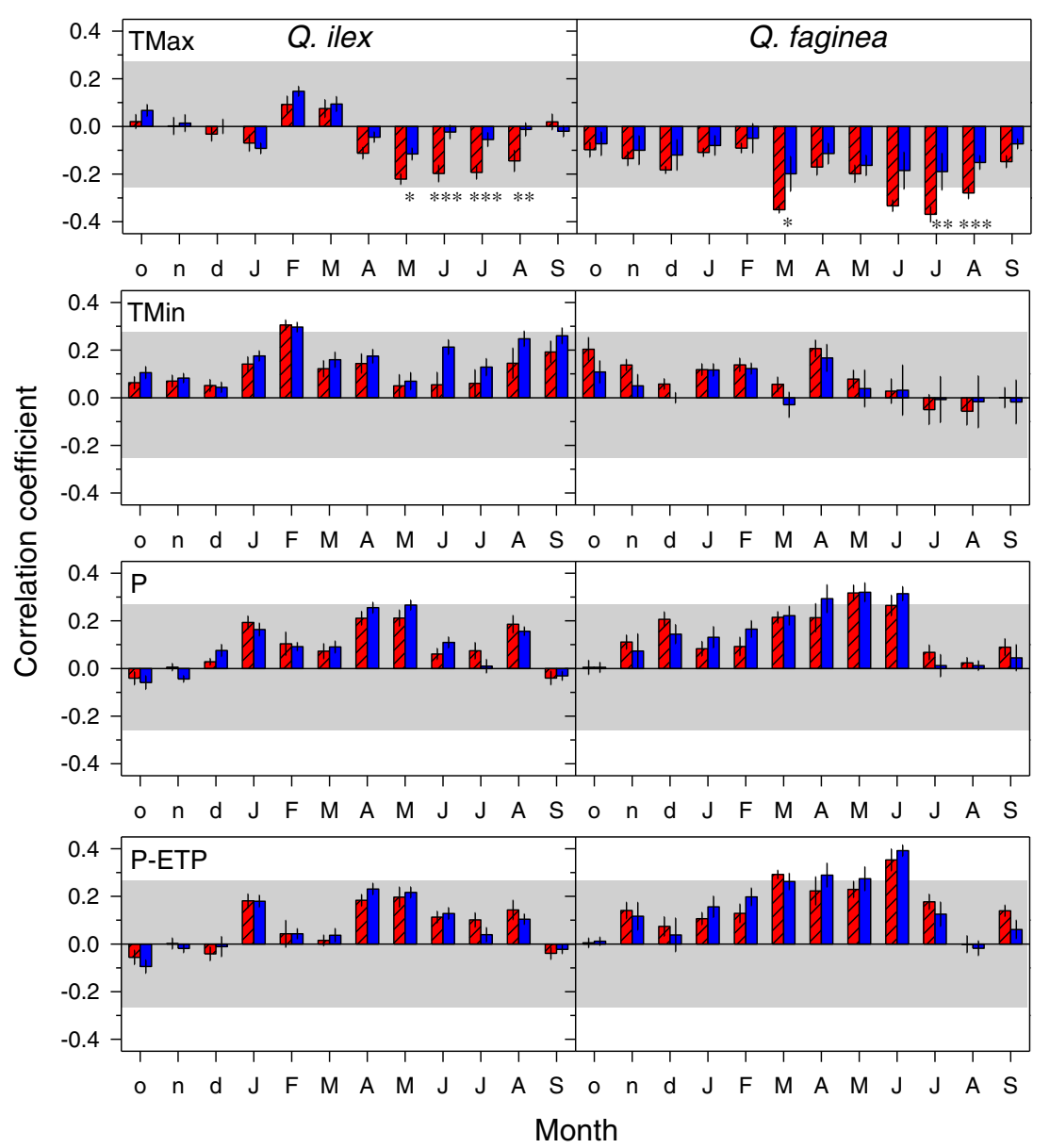

\section{Discussion}

Several factors (height, prior growth, and wood anatomy) predisposed to drought-induced dieback in the two studied Mediterranean oak species. As expected, the most defoliated holm oak individuals showed lower growth rates and vessels with smaller transversal areas than less defoliated trees prior to the dieback (Figs. 1 and 4). However, in Portuguese oak, the differences in growth (BAI) between defoliation classes appeared after the 2000s recurrent droughts, and more defoliated trees showed a slightly higher mean earlywood vessel area.

Holm oak trees showing lower growth rates and producing vessels with smaller areas were more prone to drought-induced leaf shedding and dieback. Our findings partially coincide with results obtained from rainfall exclusions showing how drought precludes shoot extension and reduces leaf production in this species (Ogaya and Peñuelas 2006; Limousin et al. 2010; Misson et al. 2011). However, these exclusions did not usually alter xylem vessel area. Therefore, changes in the transpiring leaf area seem to be a fast morphological adjustment adopted to cope with the increased transpiration demand. In the field, intense droughts are associated to reduced growth and the formation of narrow vessels in holm oak (Corcuera et al. 2004a) and other Mediterranean oak species (Corcuera et al. 2004b; Gea-Izquierdo et al. 2012). These modifications in wood anatomical features suggest that intense or long-lasting droughts modify wood formation and probably make affected trees less resilient after the drought ceases, whereas defoliation is a more rapid response to water shortage (Eilmann et al. 2013). Overall, wood anatomy and growth data suggest that a long-term hydraulic deterioration influenced the defoliation and dieback intensity observed in holm oak.

Portuguese oak trees grew at high rates and were characterized by being very responsive to the water balance and forming wide conduits. Fast-growing trees located in xeric sites depend on fluctuating soil water sources (Bendixsen et al. 2015), but the soils in the study site were rocky and shallow which suggests Portuguese oak should reach accessible soil reserves. In fact, the Portuguese oak is able to hold higher soil water contents in the upper layers under its canopy than the holm oak 
Fig. 4 Vessel area distributions observed for holm (Q. ilex) and Portuguese oak ( $Q$. faginea) in trees with low (crown cover> $50 \%$ ) and high (crown cover $\leq$ $50 \%$ ) defoliation levels. Graphs were built considering all measured vessels (a) or mean annual vessel areas (b). The number of measured vessels is indicated in the upper plots. Box plots show the median, the 25th (box boundary closest to zero) and 75th (box boundary farthest from zero) percentiles, the 10th and 90th percentiles (error bars), and the 5th and 95th percentiles (symbols) (a)

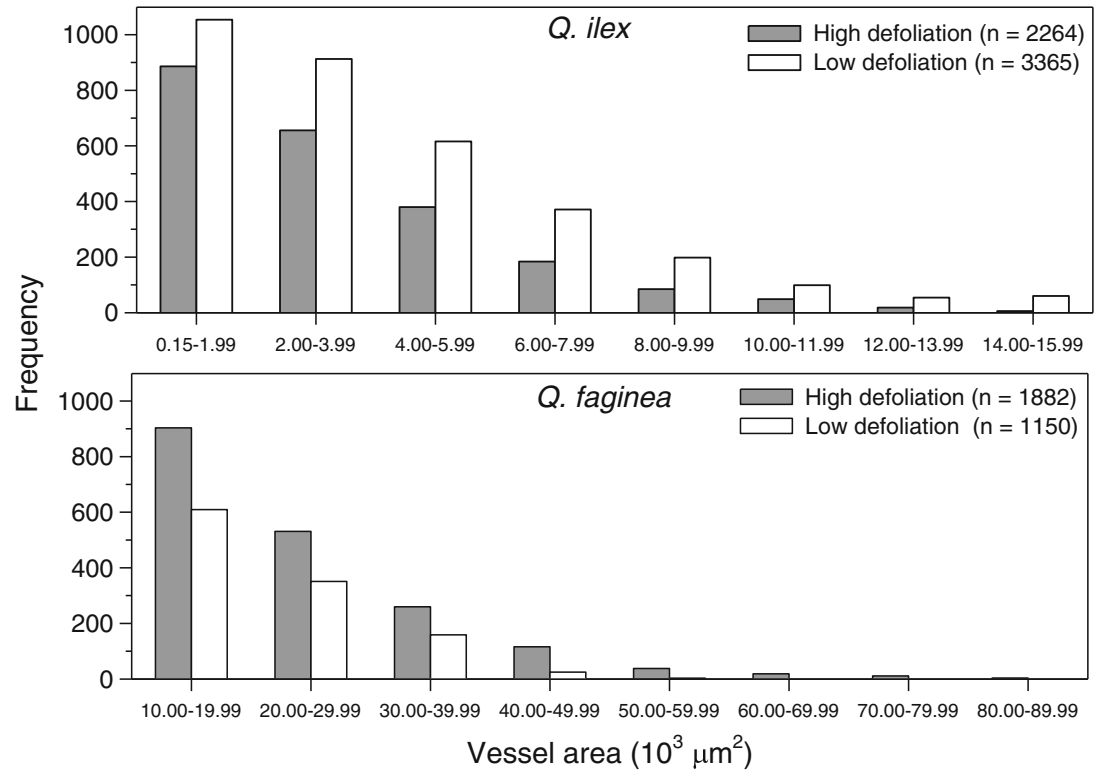

(b)

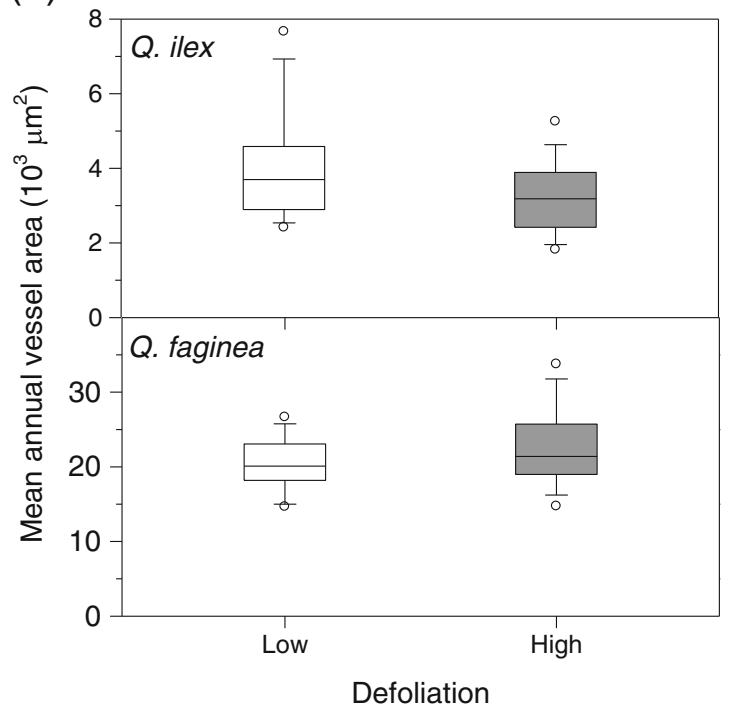

epicormic shoots to restore the canopy after droughts, whereas the holm oak could form new shoots from older buds.

Warm and dry conditions in spring and summer were associated to reduced growth (Fig. 2), but such reduction intensified as defoliation increased in both tree species, being significant only in the Portuguese oak (Fig. 3). This is in agreement with the most pronounced seasonal responses to climatic stressors of deciduous tree species in forests subjected to continental and Mediterranean conditions (Granda et al. 2014). Growth in the deciduous oak species responded more negatively to spring heat stress, and this translated into increased defoliation and growth 
Table 3 Concentrations (\%) of non-structural carbohydrates (soluble sugars, starch, NSC) measured in several organs or tissues of holm and Portuguese oak trees showing contrasting defoliation degrees

\begin{tabular}{|c|c|c|c|c|c|c|c|c|}
\hline \multirow[t]{3}{*}{ Sampling year } & \multirow[t]{3}{*}{ Organ or tissue } & \multirow[t]{3}{*}{ Chemical element } & \multicolumn{3}{|c|}{ Holm oak (Quercus ilex) } & \multicolumn{3}{|c|}{ Portuguese oak (Quercus faginea) } \\
\hline & & & \multicolumn{2}{|c|}{ Defoliation degree } & \multirow[t]{2}{*}{$F(P)$} & \multicolumn{2}{|c|}{ Defoliation degree } & \multirow[t]{2}{*}{$F(P)$} \\
\hline & & & High & Low & & High & Low & \\
\hline \multirow[t]{6}{*}{2013} & \multirow[t]{3}{*}{ Leaves } & SS & $4.69 \pm 0.17$ & $5.22 \pm 0.35$ & $1.68(0.22)$ & $6.58 \pm 0.29$ & $6.44 \pm 0.38$ & $0.08(0.78)$ \\
\hline & & Starch & $3.85 \pm 0.20$ & $4.02 \pm 0.15$ & $0.49(0.50)$ & $5.47 \pm 0.41$ & $5.65 \pm 0.25$ & $0.14(0.72)$ \\
\hline & & NSC & $8.54 \pm 0.31$ & $9.23 \pm 0.27$ & $2.90(0.11)$ & $12.05 \pm 0.31$ & $12.09 \pm 0.54$ & $0.01(0.95)$ \\
\hline & \multirow[t]{3}{*}{ Shoots } & SS & $3.12 \pm 0.19$ & $3.34 \pm 0.23$ & $0.55(0.47)$ & $3.71 \pm 0.13$ & $3.33 \pm 0.25$ & $1.81(0.22)$ \\
\hline & & Starch & $3.75 \pm 0.19$ & $4.27 \pm 0.26$ & $2.69(0.12)$ & $4.53 \pm 0.36$ & $4.01 \pm 0.28$ & $1.30(0.29)$ \\
\hline & & NSC & $6.86 \pm 0.20$ & $7.61 \pm 0.42$ & $2.81(0.11)$ & $8.23 \pm 0.47$ & $7.34 \pm 0.49$ & $1.70(0.23)$ \\
\hline \multirow[t]{9}{*}{2014} & \multirow[t]{3}{*}{ Leaves } & SS & $3.46 \pm 0.27$ & $3.09 \pm 0.45$ & $2.84(0.17)$ & $3.98 \pm 0.17$ & $3.68 \pm 0.21$ & $1.24(0.30)$ \\
\hline & & Starch & $4.40 \pm 0.30$ & $4.06 \pm 0.82$ & $1.00(0.37)$ & $5.18 \pm 1.11$ & $5.56 \pm 0.55$ & $0.10(0.77)$ \\
\hline & & NSC & $7.86 \pm 0.37$ & $7.15 \pm 0.40$ & $0.30(0.61)$ & $9.16 \pm 1.08$ & $9.25 \pm 0.54$ & $0.05(0.95)$ \\
\hline & \multirow[t]{3}{*}{ Shoots } & SS & $2.30 \pm 0.17$ & $2.13 \pm 0.20$ & $0.40(0.56)$ & $2.03 \pm 0.22$ & $1.84 \pm 0.06$ & $0.74(0.41)$ \\
\hline & & Starch & $2.77 \pm 0.17$ & $2.63 \pm 0.05$ & $0.43(0.54)$ & $3.84 \pm 0.51$ & $4.18 \pm 0.29$ & $0.35(0.57)$ \\
\hline & & NSC & $5.07 \pm 0.27$ & $4.77 \pm 0.16$ & $0.75(0.43)$ & $5.87 \pm 0.67$ & $6.02 \pm 0.32$ & $0.04(0.84)$ \\
\hline & \multirow[t]{3}{*}{ Sapwood } & SS & $1.64 \pm 0.17$ & $1.92 \pm 0.16$ & $1.28(0.28)$ & $1.36 \pm 0.12$ & $1.58 \pm 0.16$ & $1.20(0.31)$ \\
\hline & & Starch & $1.58 \pm 0.14$ & $3.35 \pm 0.32$ & $15.38(0.001)$ & $2.23 \pm 0.16$ & $2.24 \pm 0.16$ & $0.01(0.97)$ \\
\hline & & NSC & $3.23 \pm 0.30$ & $5.25 \pm 0.28$ & $20.33(0.0004)$ & $3.59 \pm 0.27$ & $3.82 \pm 0.17$ & $0.51(0.49)$ \\
\hline
\end{tabular}

Tissues were sampled in November 2013 and July 2014 except stem sapwood which was sampled in July 2014. Comparisons between defoliation classes are based on one-way ANOVAs, and significant $F$ statistics $(P<0.05)$ are shown in bold

SS soluble sugars, NSC total non-structural carbohydrates

decline but not into NSC depletion. This heat stress may act by amplifying summer drought stress thus reducing earlywood formation.

A common feature observed in highly defoliated trees was their smaller height as compared with less defoliated individuals. However, the study site is a low coppice stand so any explanation related to hydraulic limits imposed by tree height is not plausible (cf. Ryan and Yoder 1997). In the Mediterranean Basin, resprouting oak species have been usually managed as coppice systems (Serrada et al. 1992). Coppice oak stands accumulate a belowground biomass greater or equal than that displayed aboveground due to root and stump resprouting (Canadell and Rodà 1991). We suggest that the imbalanced root/shoot ratios of coppice oaks could magnify the competition for water within the stools of the same individual making higher individuals more prone to drought-induced defoliation (Corcuera et al. 2006). Thus, previous forest use can predispose to drought-induced dieback by affecting aboveground productivity in coppice oaks.

In Norway spruce trees subjected to an experimental drought, only root carbon pools were reduced when trees died (Hartmann et al. 2013). Hence, sampling root systems could be further considered in future research to test if the decline in sapwood starch observed in highly defoliated holm oaks corresponds to a reduction of belowground carbon pools. In addition, the reported defoliation-height association should be further tested in more coppice oak species where detailed analyses of the actual soil water available to trees at different depths are urgently needed.

To conclude, coexisting oak species were differently predisposed to drought and heat stress as a function of prior growth (tree height, wood formation) and vessel lumen area. In both oak species, defoliation increased as prior tree height decreased, i.e., we detected a size-dependent predisposition to dieback. The reduced growth and vessel area prior to dieback of highly defoliated holm oak trees indicate that in this species, slow-growing trees are more prone to post-dieback defoliation and a decrease in the sapwood starch concentration. Contrastingly, in the Portuguese oak, the most predisposed trees to drought-related defoliation showed the highest growth responsiveness to warm spring and summer temperatures, i.e., they were particularly sensitive to elevated evapotranspiration rates during the growing season which reduced radial growth. These findings emphasize the role played by species and individual-specific traits as predisposing factors to droughtinduced dieback. Traits such as growth seasonality, tree size, growth rate and responsiveness to climate, and xylem vessel area filter how soil moisture deficit translates into drought damage in trees. 
Acknowledgments We sincerely thank E. Lahoz and M. Maestro for their help with chemical analyses. We thank R. Hernández and Formiche forest guards (Aragón Government) for their guidance in the field and elsewhere. We acknowledge collaborative work and discussions supported by the Studying Tree Responses to extreme Events: a SynthesiS (STReESS) EU COST Action FP1106.

Funding This project was supported by project CGL2011-26654 (Economy and Innovation Ministry, Spain).

\section{References}

Abramoff MD, Magalhaes PJ, Ram SJ (2004) Image processing with ImageJ. Biophot Int 11:36-42

Albuixech J, Camarero JJ, Montserrat-Martí G (2012) Dinámica estacional del crecimiento secundario y anatomía del xilema en dos Quercus mediterráneos que coexisten. For Syst 21:9-22

Alla AQ, Camarero JJ (2012) Contrasting responses of radial growth and wood anatomy to climate in a Mediterranean ring-porous oak: implications for its future persistence or why the variance matters more than the mean. Eur J For Res 131:1537-1550

Alla AQ, Camarero JJ, Palacio S, Montserrat-Martí G (2013) Revisiting the fate of buds: size and position drive bud mortality and bursting in two coexisting Mediterranean Quercus species with contrasting leaf habit. Trees Struct Funct 27:1375-1386

Allen CD, Macalady AK, Chenchouni H, Bachelet D, McDowell N, Vennetier M, Kitzberger T, Rigling A, Breshears DD, Hogg EH, González P, Fensham R, Zhang Z, Castro J, Demidova N, Lim JH, Allard G, Running SW, Semerci A, Cobb N (2010) A global overview of drought and heat-induced tree mortality reveals emerging climate change risks for forests. For Ecol Manag 259:660-684

Anderegg LDL, Anderegg WRL, Berry JA (2013) Not all droughts are created equal: translating meteorological drought into woody plant mortality. Tree Physiol 33:701-712

Anderegg WRL (2015) Spatial and temporal variation in plant hydraulic traits and their relevance for climate change impacts on vegetation. New Phytol 205:1008-1014

Barbaroux C, Bréda N (2002) Contrasting distribution and seasonal dynamics of carbohydrate reserves in stem wood of adult ring-porous sessile oak and diffuse porous beech trees. Tree Physiol 22:12011210

Bendixsen DP, Hallgren SW, Frazier AE (2015) Stress factors associated with forest decline in xeric oak forests of south-central United States. For Ecol Manag 347:40-48

Bréda N, Huc R, Granier A, Dreyer E (2006) Temperate forest trees and stands under severe drought: a review of ecophysiological responses, adaptation processes and long-term consequences. Ann For Sci 63:625-644

Buysse J, Merckx R (1993) An improved colorimetric method to quantify sugar content of plant tissue. J Exp Bot 44:1627-1629

Camarero JJ, Gazol A, Sangüesa-Barreda G, Oliva J, Vicente-Serrano SM (2015) To die or not to die: early warnings of tree dieback in response to a severe drought. J Ecol 103:44-57

Campelo F, Nabais C, Gutiérrez E, Freitas H, García-González I (2010) Vessel features of Quercus ilex L. growing under Mediterranean climate have a better climatic signal than tree-ring width. Trees Struct Funct 24:463-470

Canadell J, Rodà F (1991) Root biomass of Quercus ilex in a montane Mediterranean forest. Can J For Res 21:1771-1778

Cherubini P, Gartner BL, Tognetti R, Braker OU, Schoch W, Innes JL (2003) Identification, measurement and interpretation of tree rings in woody species from Mediterranean climates. Biol Rev 78:119-148
Choat B, Jansen S, Brodribb TJ, Cochard H, Delzon S, Bhaskar R, Bucci SJ, Field TS, Gleason SM, Hacke UG et al (2012) Global convergence in the vulnerability of forests to drought. Nature 491:752-755

Coll L, Camarero JJ, Martínez de Aragón J (2012) Fine root seasonal dynamics, plasticity, and mycorrhization in two coexisting Mediterranean oaks with contrasting aboveground phenology. Ecoscience 19:238-245

Corcuera L, Camarero JJ, Gil-Pelegrin E (2004a) Effects of a severe drought on Quercus ilex radial growth and xylem anatomy. Trees Struct Funct 18:83-92

Corcuera L, Camarero JJ, Gil-Pelegrín E (2004b) Effects of a severe drought on growth and wood-anatomical properties of Quercus faginea. IAWA J 25:185-204

Corcuera L, Camarero JJ, Sisó S, Gil-Pelegrín E (2006) Radial-growth and wood-anatomical changes in overaged Quercus pyrenaica coppice stands: functional responses in a new Mediterranean landscape. Trees Struct Funct 20:91-98

Dobbertin M (2005) Tree growth as indicator of tree vitality and of tree reaction to environmental stress: a review. Eur J For Res 124:319_ 333

Eilmann B, Dobbertin M, Rigling R (2013) Growth response of Scots pine with different crown transparency status to drought release. Ann For Sci 70:685-693

Fritts HC (2001) Tree rings and climate. Blackburn Press, Caldwell, NJ, USA

Gea-Izquierdo G, Fonti P, Cherubini P, Martín-Benito D, Chaar H, Cañellas I (2012) Xylem hydraulic adjustment and growth response of Quercus canariensis Willd. to climatic variability. Tree Physiol 32:401-403

Granda E, Scoffoni C, Rubio-Casal AE, Sack L, Valladares F (2014) Leaf and stem physiological responses to summer and winter extremes of woody species across temperate ecosystems. Oikos 123:1281-1290

Gutiérrez E, Campelo F, Camarero JJ, Ribas M, Muntán E, Nabais C, Freitas H (2011) Climate controls act at different scales on the seasonal pattern of Quercus ilex L. stem radial increments in NE Spain. Trees Struct Funct 25:637-646

Gutschick VP, BassiriRad H (2003) Extreme events as shaping physiology, ecology, and evolution of plants: toward a unified definition and evaluation of their consequences. New Phytol 160:21-42

Hargreaves GH, Samani ZA (1982) Estimating potential evapotranspiration. J Irrig Drain Eng 108:225-230

Hartmann H, Ziegler W, Trumbore S (2013) Lethal drought leads to reduction in nonstructural carbohydrates in Norway spruce tree roots but not in the canopy. Funct Ecol 27:413-427

Hoch G, Richter A, Körner C (2003) Non-structural carbon compounds in temperate forest trees. Plant Cell Environ 26:1067-1081

Hoffmann WA, Marchin RM, Abit P, Lau OL (2011) Hydraulic failure and tree dieback are associated with high wood density in a temperate forest under extreme drought. Glob Chang Biol 17:2731-2742

Holmes RL (1983) Computer-assisted quality control in tree-ring dating and measurement. Tree-Ring Bull 43:69-78

Hsiao TC (1973) Plant responses to water stress. Annu Rev Plant Physiol Plant Mol Biol 24:519-570

IPCC (2014) Climate change 2014: impacts, adaptation, and vulnerability. Part B: regional aspects. Contribution of Working Group II to the Fifth Assessment Report of the Intergovernmental Panel on Climate Change. Barros VR, Field CB, Dokken DJ, Mastrandre MD (eds). Cambridge University Press, Cambridge

Limousin JM, Longepierre D, Huc R, Rambal S (2010) Change in hydraulic traits of Mediterranean Quercus ilex subjected to long-term throughfall exclusion. Tree Physiol 30:1026-1036

McDowell NG, Pockman WT, Allen CD, Breshears DD, Cobb N, Kolb T, Plaut J, Sperry JS, West A, Williams DG et al (2008) Mechanisms of plant survival and mortality under drought: why do some plants survive while others succumb to drought? New Phytol 178:719-739 
Meinzer FC, Johnson DM, Lachenbruch B, McCulloh KA, Woodruff DR (2009) Xylem hydraulic safety margins in woody plants: coordination of stomatal control of xylem tension with hydraulic capacitance. Funct Ecol 23:922-930

Misson L, Degueldre D, Collin C, Rodriguez R, Rocheteau A, Ourcival JM, Rambal S (2011) Phenological responses to extreme droughts in a Mediterranean forest. Glob Ch Biol 17:1036-1048

Montserrat-Martí G, Camarero JJ, Palacio S, Pérez-Rontomé C, Milla R, Albuixech J, Maestro M (2009) Summer-drought constrains the phenology and growth of two co-existing Mediterranean oaks with contrasting leaf habit: implications for their persistence and reproduction. Trees Struct Funct 23:787-799

Mudelsee M (2003) Estimating Pearson's correlation coefficient with bootstrap confidence interval from serial dependent time series. Math Geol 35:651-665

Muller B, Pantin F, Génard M, Turc O, Freixes S, Piques M, Gibon Y (2011) Water deficits uncouple growth from photosynthesis, increase $\mathrm{C}$ content, and modify the relationships between $\mathrm{C}$ and growth in sink organs. J Exp Bot 62:1715-1729

Nardini A, Battistuzzo M, Savi T (2013) Shoot desiccation and hydraulic failure in temperate woody angiosperms during an extreme summer drought. New Phytol 200:322-329

Ogaya R, Peñuelas J (2006) Contrasting foliar responses to drought in Quercus ilex and Phillyrea latifolia. Physiol Plant 50:373-382

Pasho E, Camarero JJ, de Luis M, Vicente-Serrano SM (2011) Impacts of drought at different time scales on forest growth across a wide climatic gradient in north-eastern Spain. Agric For Meteorol 151: $1800-1811$

Peguero-Pina JJ, Sancho-Knapik D, Barrón E, Camarero JJ, Vilagrosa A, Gil-Pelegrín E (2014) Morphological and physiological divergences within Quercus ilex support the existence of different ecotypes depending on climatic dryness. Ann Bot 114:301-313
R Development Core Team (2015) R: a language and environment for statistical computing. R Foundation for Statistical Computing, Vienna, Austria. http://www.R-project.org.

Ryan MG, Yoder BJ (1997) Hydraulic limits to tree height and tree growth. Bioscience 47:235-242

Sala A, Woodruff DR, Meinzer FC (2012) Carbon dynamics in trees: feast or famine. Tree Physiol 32:764-775

Schomaker ME, Zarnoch SJ, Bechtold WA, Latelle DJ, Burkman WG, Cox SM (2007) Crown-condition classification: a guide to data collection and analysis. USDA For Serv, Gen. Tech. Rep. SRS-102. Asheville, NC. $78 \mathrm{p}$

Serrada R, Allué M, San Miguel A (1992) The coppice system in Spain. Current situation, state of art and major areas to be investigated. Ann Ist Sper Selvic 23:266-275

Sevanto S, McDowell NG, Dickman LT, Pangle R, Pockman WT (2014) How do trees die? A test of the hydraulic failure and carbon starvation hypotheses. Plant, Cell \& Env 37:153-161

Sperry JS, Love DM (2015) What plant hydraulics can tell us about responses to climate-change droughts. New Phytol. doi:10.1111/ nph. 13354

Tardieu F, Granier C, Muller B (2011) Water deficit and growth. Coordinating processes without an orchestrator? Curr Opin Plant Biol $14: 283-289$

Tognetti R, Longobucco A, Raschi A (1998) Vulnerability of xylem to embolism in relation to plant hydraulic resistance in Quercus pubescens and Quercus ilex co-occurring in a Mediterranean coppice in central Italy. New Phytol 139:437-447

Vicente-Serrano SM, Beguería S, López-Moreno JI (2010) A multiscalar drought index sensitive to global warming: the standardized precipitation evapotranspiration index. J Clim 23:1696-1718 